\title{
Cryotherapy of proliferative sickle retinopathy, II: triple freeze-thaw cycle
}

\author{
MICHAEL H. GOLDBAUM, ROBERT C. FLETCHER, LEE M. JAMPOL, AND \\ MORTON F. GOLDBERG
}

From the Sickle Cell Eye Clinic, University of Illinois Eye and Ear Infirmary, Chicago

\begin{abstract}
SUMMARY Complete closure of retinal neovascularisation due to proliferative sickle cell retinopathy was achieved in 28 'sea fans' (areas of neovascularisation) in 9 eyes of 9 patients by means of a triple freeze-thaw technique. However, 2 eyes developed subsequent rhegmatogenous retinal detachments, presumably related to vitreous traction on necrotic retina. We therefore recommend photocoagulation as the best treatment of proliferative sickle cell retinopathy. If opacities in the media prevent photocoagulation, a single freeze-thaw cycle is preferable.
\end{abstract}

Persons with sickle cell anaemia (haemoglobin SS), sickle cell B thalassaemia (haemoglobin S-Thal), and especially sickle cell haemoglobin $\mathrm{C}$ disease (haemoglobin SC) develop vasoproliferation from the retina into the vitreous. Left untreated, these areas of neovascularisation (sea fans) may progress to vitreous haemorrhage, tractional retinal detachment or rhegmatogenous retinal detachment (Goldberg, 1971). Photocoagulation with the xenon arc or argon laser has been used to destroy neovascular tissue (Goldberg and Acacio, 1973; Goldbaum et al., 1977). For successful photocoagulation the media must be sufficiently clear over the feeding vessels to allow the photocoagulation beam to form a sharp image in the retina. Vitreous haemorrhage or other opacities in the media can prevent successful photocoagulation. Furthermore, photocoagulation has known complications such as haemorrhage (Goldbaum et al., 1977), choroidal ischaemia (Goldbaum et al., 1976), and choroidovitreal neovascularisation (Galinos et al., 1975; Goldbaum et al., 1977). A previous paper from our clinic relates our experiences with a single freezethaw cycle of transconjunctival cryopexy in the treatment of proliferative sickle retinopathy (Lee et al., 1975). Thirteen sea fans in 10 eyes of 6 patients were treated. Four of these 13 sea fans $(31 \%)$ were still patent, though markedly attenuated, after treatment. None of the attenuated sea fans has bled in the 3 years since the cryopexy.

Address for reprints: Dr Lee M. Jampol, Sickle Cell Eye Clinic, Illinois Eye and Ear Infirmary, 1855 West Taylor Street, Chicago, Illinois 60612, USA
Several authors have reported successful treatment of retinoblastomas and vascular tumours, such as retinal angiomatosis, with repeated freeze-thaw techniques (Hale and Christensen, 1968; Amoils and Smith, 1969; Welch, 1970; Watzke, 1973; Watzke, 1974). With this in mind an attempt was made to improve our previous cryotherapeutic results in proliferative sickle retinopathy by employing a triple freeze-thaw cycle.

\section{Materials and methods}

Between February 1974 and July 1974 every third eye of the patients seen at the Sickle Cell Eye Clinic of the University of Illinois Eye and Ear Infirmary that required treatment for proliferative sickle cell retinopathy and any eye in which sea fans could be identified but were partially obscured by vitreous haemorrhage were selected for triple freeze-thaw cycle cryotherapy. A total of 28 sea fans in 9 eyes of 9 patients were treated. The patients' ages ranged from 16 to 53 years, with a mean of 30 years. Seven patients had haemoglobin SC, 1 had haemoglobin SS, and 1 had haemoglobin AS (all confirmed by quantitative haemoglobin electrophoresis).

Before treatment each patient received an eye examination with measurement of best corrected visual acuity, slit-lamp examination, and a detailed retinal drawing with indirect ophthalmoscopy and scleral depression. Fluorescein angiography confirmed the patency of the sea fans to be treated. In eyes in which vitreous haemorrhage made identification of a sea fan difficult or uncertain, fluorescein angioscopy with a Wratten 47 blue filter on an 
indirect ophthalmoscope was performed to locate the telltale green vitreous cloud of fluorescein overlying each sea fan.

Each treatment was performed either with a carbon dioxide probe or a fluorocarbon probe, each
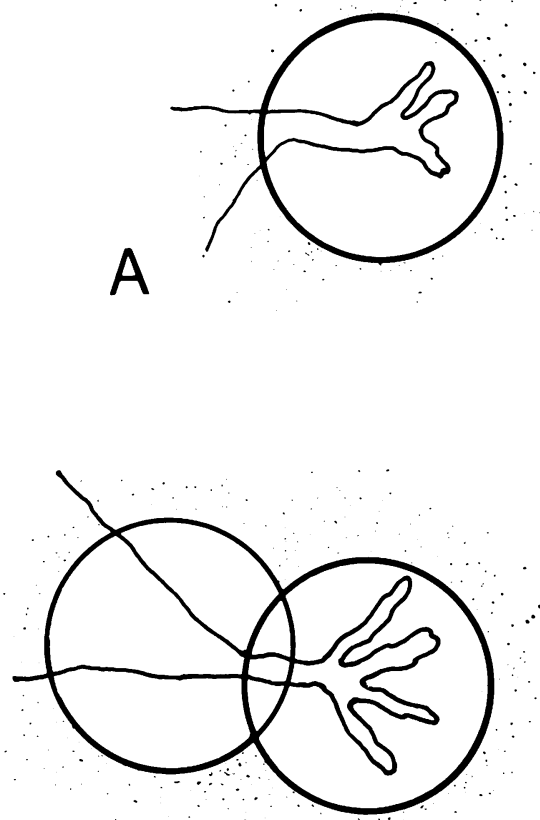

8

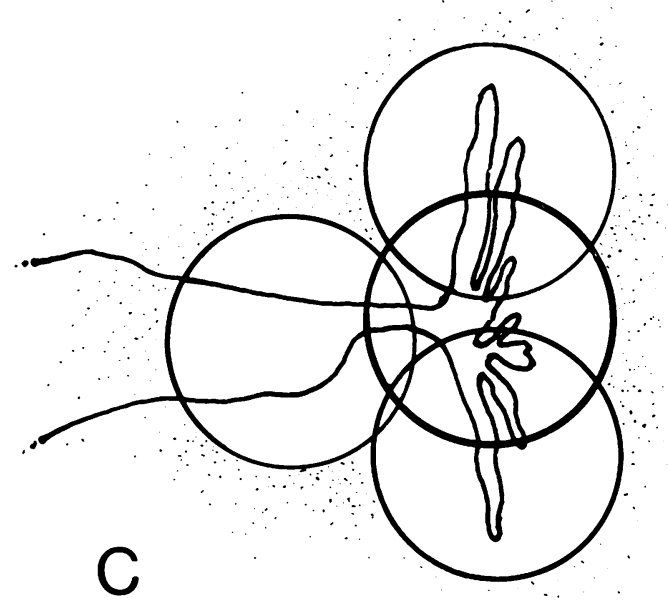

Fig. 1 Technique of triple freeze-thaw cryopexy. For a small sea fan $(A)$ a single site was treated. For a somewhat larger lesion $(B)$ the feeding vessels were treated first, followed by freezing of the lesion itself. For a large sea fan $(C)$ the feeding vessels were treated and then multiple applications were made to cover the entire lesion

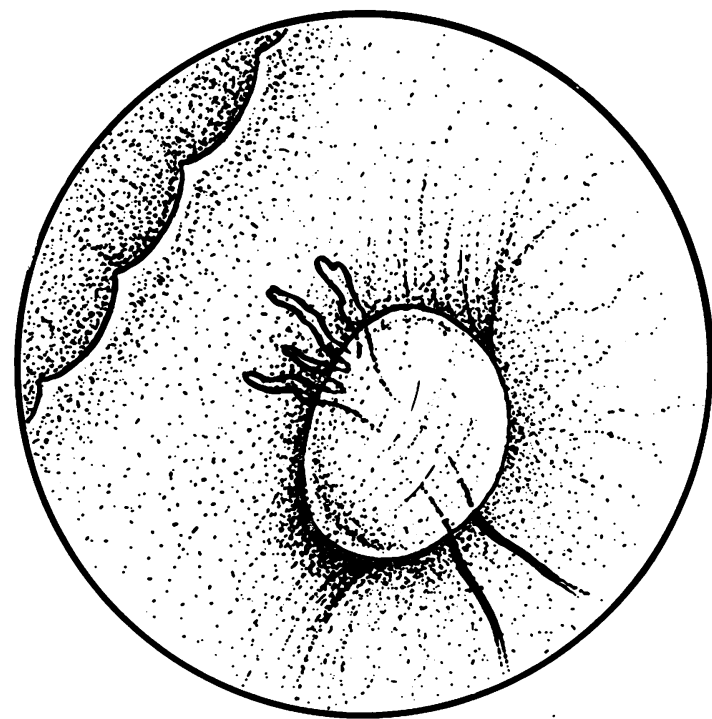

Fig. 2 Endpoint of treatment corresponded to incorporation of vessels within the iceball with a 'frosted' appearance to the vessels

adjusted for maximum cooling. The intense cryopexy was painful with topical anaesthesia. Hence $1 \%$ lignocaine was injected subconjunctivally in the quadrant to be treated, or a retrobulbar injection was given. The cryoprobe was applied to the globe directly over the site of the smaller sea fans, which were then treated with a triple freeze-thaw that totally encompassed the area of neovascularisation. Larger sea fans were first treated with a triple freezethaw cycle to the feeding vessels. The cryoprobe was then moved to adjacent sites until the entire sea fan had been covered (Fig. 1).

Each transconjunctival cryopexy lesion was monitored by indirect ophthalmoscopy. The probe was positioned to indent the desired area. The iceball was allowed to grow until the treated vessels were incorporated. The end point was a hazy appearance of the vessels to be treated within the iceball as if they were being viewed through frosted glass (Fig. 2). The process was repeated two additional times at each site of application. It is important to note that, when the vessels to be treated stood out brilliantly in relief against the white background of the iceball, the iceball had not yet reached the vessels and the end point had not yet been achieved. When vitreous haemorrhage was present and the view of the sea fan was obscured, the end point was more difficult to identify and had to be estimated.

Twenty-four or 48 hours after treatment and again several weeks later fluorescein angiography was 


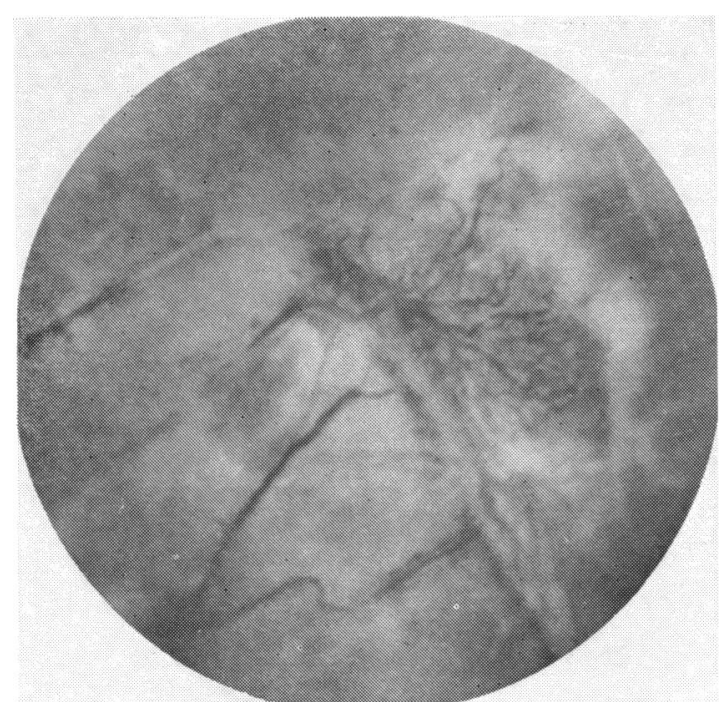

Fig. 3 Appearance of treated sea fan 1 day after cryopexy

performed to determine if the treated sea fan was perfused.

\section{Results}

After this intense cryopexy there was often considerable transient conjunctival chemosis. Blood vessels in the conjunctiva were sometimes occluded 24 to 48 hours after the treatment. After a week the conjunctiva appeared normal. No abnormalities in muscle balance were induced.

After the triple freeze-thaw applications each of the sea fans was engorged and appeared purple against a background of pale oedematous retina (Fig. 3). Fluorescein angiography 24 or 48 hours later showed non-perfusion of the treated sea fan (Fig. 4); all 28 sea fans were closed and have not reperfused over a 3-year period of observation (Fig. 5, Table 1).

In 2 of the 3 eyes with vitreous haemorrhage (Cases 2 and 4) the vitreous cleared spontaneously over the next 6 months. One patient (Case 5) with a dense central vitreous haemorrhage failed to clear over a 6-month period, though there was no evidence of rebleeding. Vitrectomy and subsequent lens extraction returned the visual acuity to $20 / 20$ with a soft contact lens.

Two of the patients (Cases 1 and 8) developed local rhegmatogenous retinal detachments shortly after treatment. These detachments were successfully treated by scleral buckling with cryopexy. In both these eyes a retinal hole appeared to have been

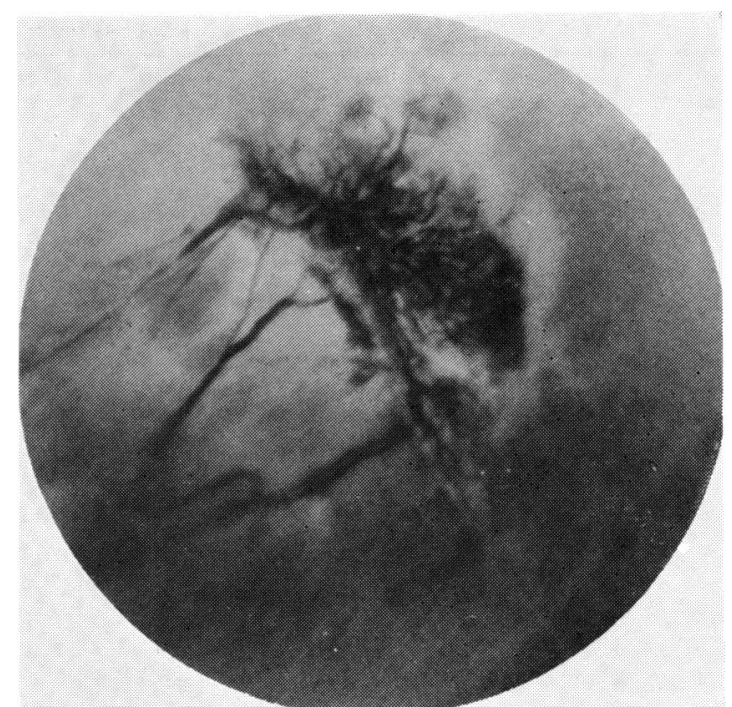

Fig. 4 Fluorescein angiography l day after treatment shows absence of perfusion

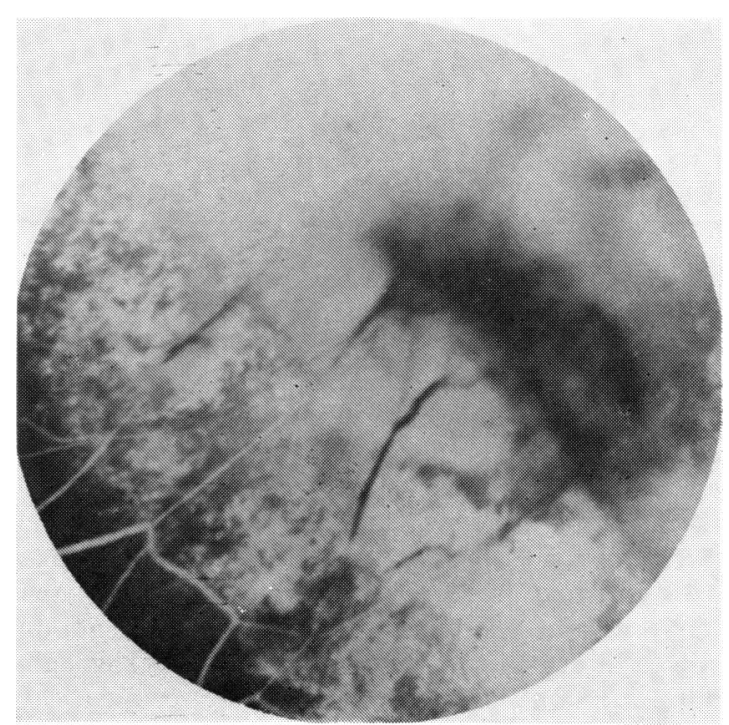

Fig. 5 Fluorescein angiography some weeks later again shows absence of perfusion of treated lesion

pulled open by vitreous traction on retina made necrotic by the triple freeze-thaw cryopexy.

\section{Discussion}

Multiple freeze-thaw cycles have certain theoretical advantages in the destruction of tissue over a single freeze cycle. Zacarian (1977) showed that 2 freeze 
Table 1 Triple freeze-thaw cryotherapy of proliferative sickle retinopatky

\begin{tabular}{|c|c|c|c|c|c|c|c|}
\hline Patient & $\begin{array}{l}\text { Haemoglobin } \\
\text { type }\end{array}$ & $\begin{array}{l}\text { Age at time } \\
\text { of treatment } \\
\text { (years) }\end{array}$ & $\begin{array}{l}\text { L̈ye } \\
\text { treated }\end{array}$ & $\begin{array}{l}\text { Site of } \\
\text { sea fan } \\
\text { (clock hours) }\end{array}$ & $\begin{array}{l}\text { Pre-op. } \\
\text { visual acuity }\end{array}$ & $\begin{array}{l}\text { Final } \\
\text { visual acuity }\end{array}$ & Comments \\
\hline 1 & SC & 20 & $\mathbf{R}$ & $\begin{array}{l}0300 \\
0800\end{array}$ & $20 / 30$ & $20 / 40$ & $\begin{array}{l}\text { Developed retinal detachment; successfully } \\
\text { repaired }\end{array}$ \\
\hline 2 & SC & 24 & $\mathbf{R}$ & $\begin{array}{l}0700 \\
0800 \\
0830 \\
0900 \\
1030\end{array}$ & $\mathrm{CF} 3 \mathrm{ft}$ & $20 / 25-3$ & $\begin{array}{l}\text { Vitreous haemorrhage prevented } \\
\text { photocoagulation }\end{array}$ \\
\hline 3 & SC & 25 & L & $\begin{array}{l}0200 \\
0300 \\
1100 \\
1200\end{array}$ & $20 / 25$ & $20 / 25$ & \\
\hline 4 & SC & 26 & $\mathbf{R}$ & $\begin{array}{l}0200 \\
0300 \\
0900 \\
1000 \\
1130\end{array}$ & $\begin{array}{l}\text { LP with } \\
\text { projection }\end{array}$ & $20 / 25$ & $\begin{array}{l}\text { Vitreous haemorrhage prevented } \\
\text { photocoagulation }\end{array}$ \\
\hline 5 & SC & 31 & $\mathbf{R}$ & $\begin{array}{l}0300 \\
1200\end{array}$ & HM & $20 / 20$ & $\begin{array}{l}\text { Vitreous haemorrhage prevented } \\
\text { photocoagulation. Vitrectomy and lens } \\
\text { extraction were subsequently performed }\end{array}$ \\
\hline 6 & SC & 34 & $\mathbf{L}$ & $\begin{array}{l}0200 \\
0330\end{array}$ & $20 / 25$ & $20 / 25$ & \\
\hline 7 & SC & 53 & $\mathbf{R}$ & $\begin{array}{l}0300 \\
1200\end{array}$ & $20 / 30$ & $20 / 40$ & \\
\hline 8 & SS & 16 & $\mathbf{R}$ & 0800 & $20 / 30$ & $20 / 25$ & $\begin{array}{l}\text { Developed retinal detachment; successfully } \\
\text { repaired }\end{array}$ \\
\hline 9 & AS & 39 & $\mathbf{L}$ & $\begin{array}{l}0200 \\
0300 \\
1000 \\
1100 \\
1130\end{array}$ & $20 / 25$ & $20 / 50$ & \\
\hline
\end{tabular}

cycles are far more lethal to suspended HeLa cells than a single cycle, and he concluded that a period of incomplete thaw permitted $10 \%$ more cells to remain viable than did a complete thaw between freezes. In experimental retinal cryopexy lesions in albino rabbits Amoils (1969) noted that a triple freeze-thaw cycle potentiated vascular damage and accelerated and intensified the exudation, stasis, and thrombosis present in such lesions. He showed that with a triple freeze-thaw technique the vascular stasis became marked within 20 minutes and involved larger choroidal veins and arteries throughout the lesion. Petechiae, presumably secondary to minute ruptures of the capillary walls, were noted on the surface of retinal angiomata and retinoblastomas treated with a triple freeze-thaw cycle, but in no case did bleeding extend into the vitreous.

In the current study complete closure of 28 sea fans was achieved with a triple freeze-thaw cycle. Unfortunately 2 of the 9 eyes treated by this method developed retinal detachments. From our experience with photocoagulation, single freeze-thaw cryopexy, and triple freeze-thaw cryopexy we consider that photocoagulation is the safest and preferred treatment for closing the circulation to a sea fan. We have discontinued triple freeze-thaw cryopexy because of the occurrence of the 2 retinal detachments. The vitreous traction that is almost invariably present with proliferative sickle retinopathy makes triple freeze-thaw cryopexy too risky. When vitreous or lenticular opacities prevent photocoagulation, but allow identification and partial visualisation of sea fans, single freeze-thaw cryopexy is an acceptable alternative to photocoagulation. Though single freeze-thaw cryopexy is not $100 \%$ effective in closing treated sea fans, none of the attenuated sea fans that were not totally closed has bled after treatment (Lee et al., 1975).

We would like to thank Drs George Asdourian, Krishan Nagpal, Dimitri Patrianakos, and Chang-Bok Lee for their assistance in the care of these patients.

This study was supported in part by contract 72-2956B and grant PHS HL15168 from the National Heart and Lung Institute, National Institutes of Health.

\section{References}

Amoils, S. P. (1969). Early cryo-surgical chorioretinal microcirculatory changes. Archives of Ophthalmology, 82, 220-228.

Amoils, S. P., and Smith, T. R. (1969). Cryotherapy of angio- 
matosis retinae. Archives of Ophthalmology, 81, 689-691.

Galinos, S. O., Asdourian, G. K., Woolf, M. B., Goldberg, M. F., and Busse, B. J. (1975). Choroido-vitreal neovascularization after argon laser photocoagulation. Archives of Ophthalmology, 93, 524-530.

Goldbaum, M. H., Galinos, S. O., Apple, D. J., Asdourian, G. K., Nagpal, K., Jampol, L., Woolf, M. B., and Busse, B. (1976). Acute choroidal ischemia as a complication of photocoagulation. Archives of Ophthalmology, 94, 10251035.

Goldbaum, M. H., Goldberg, M. F., Nagpal, K., Asdourian, G. K., and Galinos, S. O. (1977). Proliferative sickle retinopathy. In Current Diagnosis and Management of Chorioretinal Diseases, 1st edn., pp. 132-145. Edited by F. A. L'Esperance. Mosby: St. Louis.

Goldberg, M. F. (1971). Natural history of untreated proliferative sickle retinopathy. Archives of Ophthalmology, 85, 428-437.

Goldberg, M. F., and Acacio, I. (1973). Argon laser photocoagulation of proliferative sickle retinopathy. Archives of Ophthalmology, 90, 35-44.
Hale, P. N., and Christensen, R. E. (1968). Cryotherapy of retinoblastoma. Transactions of the Pacific Coast Otoophthalmologic Society, 49, 197-211.

Lee, C-B., Woolf, M. B., Galinos, S. O., Goldbaum, M. H., Stevens, T. S., and Goldberg, M. F. (1975). Cryotherapy of proliferative sickle retinopathy. Part 1 . Single freezethaw cycle. Annals of Ophthalmology, 7, 1299-1308.

Watzke, R. C. (1973). Cryotherapy for retinal angiomatosis: a clinico-pathologic report. Documenta Ophthalmologica, $35,405-411$.

Watzke, R. C. (1974). Cryotherapy for retinal angiomatosis, a clinico-pathologic report. Archives of Ophthalmology, 92, 399-401.

Welch. R. B. (1970). Von Hippel-Lindau disease: the recognition and treatment of early angiomatosis retinae and the use of cryosurgery as an adjunct to therapy. Transactions of the American Ophthalmological Society, 68, 367-424.

Zacarian, S. A. (1977). The observation of freeze-thaw cycles upon cancer cell suspensions. Journal of Dermatological Surgery and Oncology, 3, 173-174. 